\title{
高圧凍結技法を取り入れた広域透過電顕像自動取得システムの開発とその応用
}

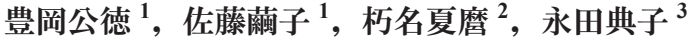 \\ 1 独立行政法人理化学研究所 環境資源科学研究センター $\bar{T} 230-0045$ 神奈川県横浜市鶴見区未広町 1-7-22 \\ 2 東京大学 大学院新領域創成科学研究科 先端生命科学専攻 ₹277-8562 千葉県柏市柏の葉 5-1-5 \\ ${ }^{3}$ 日本女子大学大学院 理学研究科 $\overline{1} 112-8681$ 東京都文京区目白台 2-8-1
}

要旨：近年, 蛍光イメージングの発展に伴い, 組織・細胞・細胞小器官・分子の動態や局在を容易に推定できるようになつ た。しかし, 各組織・細胞によ゙のような形態のオルガネラが存在し, ぞのような状態で分布しているか超微形態レベルでの実 体を把握するには, 未だに透過電子顕微鏡 (TEM) による観察が必須である. 我々は, 組織や細胞などの TEM像を広域に渡つ て自動撮影するシステムと, 撮影したTEM像をつなぎ合わせ 1 枚の高解像度 TEM 写真を取得するプログラムを組み合わせた 「広域TEM像自動取得システム」在開発した. 本システムを用いて, 植物組織や培養細胞などの数万枚の TEM像支自動撮影 し, 結合させることで, ギガピクセルクラスの写真の取得に成功している.さらに, 試料を瞬時に凍結する高圧凍結技法により, 広域超薄切片の作製に取り組み, 動的なオルガネラの分布を広域に渡り把握することに成功している. 本稿では, 広域TEM像 自動取得システムの原理と, 高圧凍結技法で作製した超薄切片から画像取得した結果を中心に紹介する.

\section{Development of high resolution TEM image acquisition system by using high- pressure freezing method}

\author{
Kiminori Toyooka ${ }^{1}$, Mayuko Sato ${ }^{1}$, Natsumaro Kutsuna ${ }^{2}$, Noriko Nagata $^{3}$ \\ ${ }^{1}$ RIKEN Center for Sustainable Resource Science, 1-7-22 Suehiro-cho, Tsurumi-ku, Yokohama, 230-0045 Japan \\ ${ }^{2}$ Department of Integrated Biosciences, Graduate School of Frontier Sciences, The University of Tokyo, Kashiwanoha, Kashiwa, $277-$ \\ 8562, Japan \\ ${ }^{3}$ Faculty of Science, Japan Women's University, Bunkyo-ku, Tokyo, 112-8681, Japan \\ Author for correspondence: K. Toyooka, toyooka@riken.jp
}

Summary: Transmission electron microscopy (TEM) is important for ultrastructure observation for organelles, cells and tissues. However, it is unsuitable for comprehensive analyses. We have constructed a high resolution TEM image acquisition system to take a giga-pixel electron micrograph. An auto-acquisition TEM system can control TEM system such as a X-Y stage, electron beam and a CCD camera by remote PC, and acquired continuous electron micrographs. We succeed in records more than 30 thousand images. We developed image-tiling program for TEM pictures, and several thousands of pictures were automatically merged. In this article, we describe the mechanism of high resolution TEM image acquisition system and the applications by using high-pressure freezing method.

Key words: transmission electron microscopy, high pressure freezing/freeze substitution, high resolution TEM image, auto-tiling

はじめに

共焦点レーザー蛍光顕微鏡なぞ光学顕微鏡機器の急速 な発達と, 蛍光タンパク質や蛍光試薬などによる蛍光ライ ブイメージング技術の発展により, 細胞小器官・分子の動 態や局在, タンパク質の発現部位を容易に推定できるよう になった．例えば植物細胞では，ミトコンドリアの融合・分 裂 (Arimura et al. 2004), 小胞体由来のERボディ(Yamada et al. 2008), ゴルジ装置の動態 (Kitajima et al. 2009) やゴル ジ体由来の小胞クラスター (Toyooka et al. 2009) など次々と 明らかになって来ている.さらに近年では, STEDやSIM, PALMなど超解像光学顕微鏡の開発により,XY 軸の空間分 解能が数十 $\mathrm{nm}$ の蛍光イメージングができるようになつてき た (Schermelleh et al. 2010). しかし, 各組織・細胞にどのよ うな形態のオルガネラが存在し, どのような状態で分布して いるか, 超微形態レベルでの実体を知るには, 蛍光イメージ ングだけでは未だ不明瞭であり, 透過電子顕微鏡 (TEM) に よる観察が必須である。
これまで筆者らは, 植物の様々な器官・組織の超微形態 観察を多数行ってきた。 その際, 常に問題になる点として, 野生型各組織における組織全体にわたつた超微細構造の報 告が少ないこと, 加えて, 組織ごとに細胞やオルガネラの超 微形態が異なることが挙げられる. それ故, 組織間・細胞間 の超微細構造の比較, 野生型と変異型とのオルガネラの比 較は難しく, 注意が必要である. また, 筆者らは組織を数十 ミリ秒で凍結固定ができる高圧凍結技法を取り入れたTEM 解析法の技術改良支進めながら, 様々な植物組織を観察し てきた. 細胞内のオルガネラ分布の微細構造解析を行った 結果, 各器官や組織の細胞ごとにゴルジ体や多胞体などオ ルガネラの分布や超微形態も大きく異なっていた. 以上の理 由から, 網羅的にオルガネラの超微細構造を撮影し, 器官 や組織ごとに解析するシステムの必要性を感じていた.

TEM は, 2000 年代初頭から今日に掛けて記録媒体がフィ ルムからデジタルへ変貌し, スロースキャン CCD カメラによ り電子線透過像をデジタルデータとして容易に保存できる 
ようになつた. さらに, コンピューターの高速化・大容量化 により画像処理や大容量データの扱いが容易になつた．そ こで筆者らは, TEMにより組織や細胞を広範囲でさらに高 解像度で超微細形態を記録することで, オルガネラの分布 や超微形態を明らかにできないかと考えた。これまでに, マ ウス神経回路網に対し, 大規模な改造を実施したTEMを用 いて広域TEM画像を取得, 解析した報告がある (Bock et al. 2011).しかし, 汎用の透過電顕を用いて簡便に TEMの広 域画像を取得する手法については, 今までに報告例はない。 当初我々は, 手動で試料ステージを動かしながら, 連続す るTEM像を数十〜数百枚撮影し, つなぎ合わせることを試 みたが, 多大な時間と労力を費やす必要があった。そこで, TEMにより連続したデジタル写真を数千枚, 数万枚と自動 撮影し, さらに自動で写真をつなぎ合わせて高解像度 TEM 写真支得る「広域TEM像自動取得システム」の開発を試み た. 本稿では, その原理と高圧凍結技法で作製した超薄切 片から画像取得した結果を中心に紹介する.

\section{広域 TEM像自動取得システムの概要}

2000 年代初頭からスロースキャン CCD カメラを標準装備 したデジタル TEMが登場し, さらに試料 X-Y ステージの移 動が手動式回転ノブからトラックボールまたはジョイステイッ クによる電動ステージ方式に替わつた。アナログ制御が一 部あったTEM本体が, 全てデジタル制御可能になったこと
で, TEM像を自動撮影する環境が整つたと言える. 我々が 使用している透過電影 (日本電子 JEM-1400) は, モーター 制御電動X-Y ステージを備え, 電子ビームを偏向コイルで コントロールすることで最大縦 5 枚 $\times$ 横 5 枚, 計 25 枚を撮影 し, 像を結合するオートモンタージュ撮影機能を標準装備す る.しかし, 電子線を偏向コイルにより曲げて撮影するオー トモンタージュ機能では, 限られた領域しか撮影できない ため, より広い領域を撮影する場合はステージを移動させる 必要がある. 試料ステージの自動制御によりオートモンター ジュ撮影が可能な他メーカーの TEM も存在するが, OS やソ フトウェア上の問題から, 撮影上限が制限されている. そこ で電子顕微鏡を専門とする研究者と画像情報解析を専門と する研究者, そして, 顕微鏡企業の協力により「広域TEM像 自動取得システム」の開発を行った.

広域 TEM像自動取得システムは, プログラムで制御する 二つのシステム, (1) 広域TEM像自動撮影システムと, (2) 広域TEM像タイリングプログラムで構成されている(図 1). （1）は, TEM本体を外部制御コンピューターによりスクリプ 卜制御し, データ保存先が許す限りの連続写真を「自動撮影」 するシステムである(図1左, 図2)。(2) は, 撮影したこれら 大量の連続画像の位置情報とのりしろ部分の画像情報走用 いて「自動結合」し, 連結した 1 枚の写真を生成するプログラ ムである(図1右, 図3).
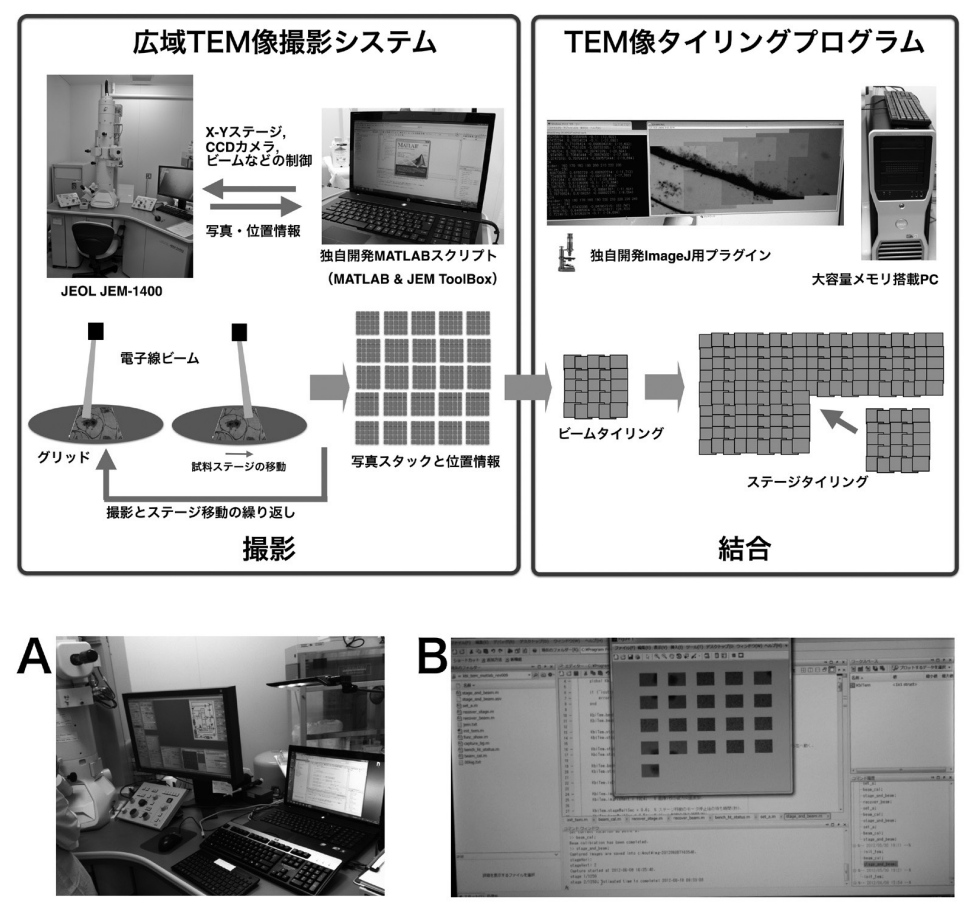

C

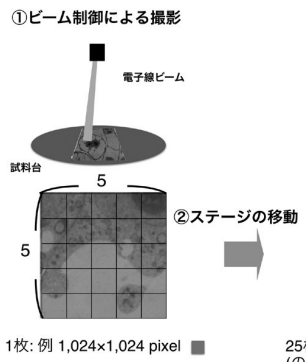

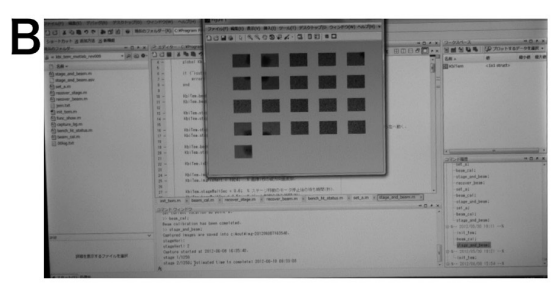

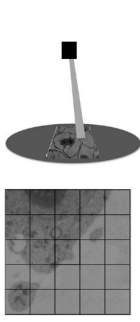

25枚: 例 $4,500 \times 4,500$ pixe
(のりしろの量 $(\%)$ に依存)
(1)と(2)を繰り返す

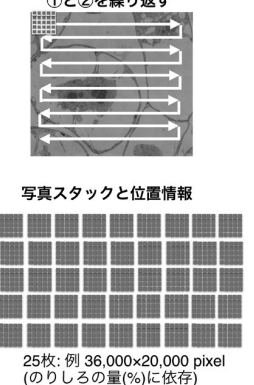

図 1 広域TEM像自動取得システムの概要. 広域TEM 像自動取得システムは, プログラムで制御する二つのシ ステムで構成されている：(1) TEM本体を外部制御コン ピューターにより制御し, 連続写真を自動撮影する「広域 TEM像自動撮影システム」. (2) 撮影した大量の連続画像 在試料位置情報と画像情報在用いて「自動結合」し, 連結 した1枚の写真を生成する「TEM像タイリングプログラム」.

図2 広域TEM像自動撮影システムの概要. (A) TEM 標準制御PC モニターと外部制御用ノート型PC. (B) 広域 TEM像自動撮影 MATLAB スクリプトが害行中の外部制御 PC の画面. 数秒ごとに撮影された $\mathrm{TEM}$ 写真が 1 枚ずつ 25 枚表示され, 撮影状態が確認できる. (C) 広域TEM像自 動撮影システムの流れ：(1)ビ一ムの照射方向走変えてい き, 最大 $5 \times 5$ 枚の画像支撮影, (2) のりしろ領域支考慮し, 指定した方向・距離だけステージを移動させる. (1), (2) の動作を繰り返し，大量の連続画像を得る. 
（1）広域TEM像自動撮影システム：

事前にTEM本体側で, 撮影倍率や電子線の明るさ, フォー カスなどをあらかじめ設定した後, LAN 接続した外部制御 用ノートPCからコマンドをTEM本体へ送信することで写真 を取得する(図2A)，広域TEM像自動撮影システムの流れ は, (1) 偏向コイルを制御し, 電子ビームの照射方向を変え ることで, 連続画像を撮影する (最大 $5 \times 5$ 枚, 計 25 枚. 図 2B), (2) 指定した方向・距離だけ試料ステージをX-Y方向 に移動させる. (1)-(2)の動作を繰り返し, 大量の連続画像を 得る (図 $2 \mathrm{C}$ ). TEM をコントールするためのコマンドッー ルとして, システムインフロンティア社の JEM ToolBox t用 いている.JEM ToolBoxは日本電子製の TEM を制御する機 能を, MathWorks 社の数值解析ソフトウェアMATLAB に付 加することができ, MATLAB スクリプトによりTEM本体の試 料X-Y ステージ, CCDカメラ, 偏向コイルなどを外部コン ピューターから制御することが可能となる。筆者らはシステ ムインフロンティア社から提供された基本スクリプトに改良 走加え, 実際にTEMでスクリプトを実行しながら, 連続撮影 テストを繰り返した。

撮影した画像を結合するためには十分な“のりしろ”を確 保する必要がある. 改良スクリプトでは, 撮影時の「のりし ろ」の大きさを, 任意に設定できるようにした，さらに，ビー ム制御で撮影する枚数, ステージ移動回数, ステージ移動 から撮影までの待機時間, 撮影開始と終了位置などのパラ メータを, 用途に応じて予め設定できるようにした。 また, 撮影開始後, 撮影状態 (ステージ数), 撮影終了予想日時が 表示されるとともに，つなぎ合わせに重要な情報である画像

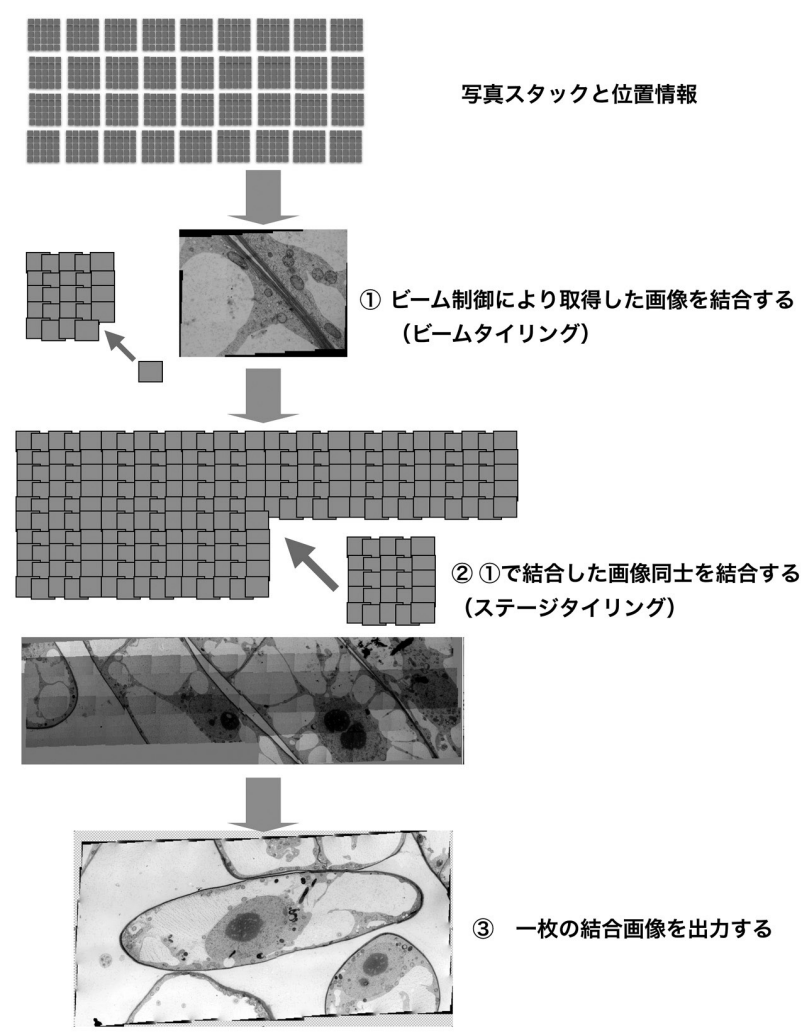

図3 TEM像タイリングプログラムの概要. TEM像タイリングプログ ラムの流れ：撮影した画像情報と位置情報を元に, (1) ビーム制御に より取得した画像を結合, (2) (1)で結合した画像同士を結合, (3)一枚 の結合画像老力.
の位置情報を記録ファイルに出力されるようにした。最適な 撮影条件を検討し, 広域 TEM像撮影を試みた結果, 2 万枚 超の画像を完全自動で取得することに何度も成功し, 最大 で46,000枚の写真を連続撮影することができた。全体の撮 影時間は倍率やパラメータ設定によって変わるが, 1,000 2,000 枚であれば 1 ～時間で撮影可能である. 2 万枚超の 一例として, 22,800枚 (撮影面積約 $110 \mu \mathrm{m} \times 180 \mu \mathrm{m}$ ) の画 像では，撮影完了までに 30 時間 37 分であった。

(2) 広域TEM像タイリングプログラム :

デジタル写真のつなぎ合わせ (タイリング) は, 市販のデ ジタルカメラやAdobe Photoshop ぞ画像ソフトウェアで容 易に合成できるようになった. 生物学の分野でも, 光学顕微 鏡により撮影した組織染色切片や蛍光像のタイリングは顕微 鏡付属のソフトゥェアで簡単に行えるようになっている.し かし, グレースケールの TEM写真はカラー写真に比べ $1 / 3$ の画像情報しかない上, 植物細胞や植物組織にはタイリン グの目印となる構造体をほとんど含まない巨大液胞と細胞 間隙が多いため市販のソフトウェアではタイリングが難しい. そこで筆者らはコマンドラインで実行するJavaアプリケーショ ンを開発し, 次の (1)〜 (3)の順でプログラム処理を行っている. (1) ビーム制御により取得した画像を結合 (ビームタイリング), (2) (1)で結合した画像同士走結合 (ステージタイリング), そ して, (3)一枚の結合画像走出力する (図 3).このプログラム は広域TEM 自動撮影時に出力してある位置情報やのりしろ の情報をもとに, 正しい順序で画像を整列し, のりしろ部分 の局所的な画像情報を元に独自の画像処理アルゴリズムを 用いることで, 短時間でタイリングが可能になっている.

本プログラムで, 液胞や細胞間隙をほとんど含まない植 物組織と動物細胞では高い精度で画像をつなぎ合わせるこ とに成功している．タイリング全体にかかる時間は，PCの CPU速度や搭載メモリ量, タイリング設定や画像内容に依 存する. 例として, 根端を撮影した 13,650 枚の画像では, 夕 イリング全体で59時間 7 分であった (8 core CPU, メモリ 128 GB の場合). タイリングの目安となる構造が少なく, ステー ジタイリングでずれが発生する場合, または, 撮影中に電子 線による損傷や熱により像の歪みが発生している場合は, 本 プログラムのビームタイリングプログラムでつなぎ合わせた ビームタイリング像を, Photoshopの手動ソートと自動合成 ツールにより半自動的に合成することで, 結合精度の高い 1 枚のタイリング像を得ている.

結合画像は一辺が数万〜数十万ピクセル, 数 $\mathrm{GB} \sim$ 数十 GB と巨大ファイルになる. 現状では, 画素数が 2 ギガピク セルを超えると, 1 枚の 2 次元画像として扱うことは困難であ る. 広域TEM像タイリングプログラムでは, 最終的な出力 画像のサイズを任意に縮小できるようなパラメータ設定も行 える. Photoshopt併用した半自動合成の場合は, Photoshop 形式 (最大 $2 \mathrm{~GB}$ ) またはビックドキュメント形式 (一辺の最大 300,000 ピクセル) で保存, 使用目的にあわせて解像度を調 整し TIFF (最大 $4 \mathrm{~GB})$ やJPEG (最大 $30,000 \times 30,000$ ピクセ ル)等に書き出している.

\section{高圧凍結技法による広域凍結試料作製}

組織や細胞に固定液を徐々に浸透させる化学固定による 試料調製法では, 細胞内でダイナミックに動くゴルジ体や多 
胞体なぞ，膜輸送系オルガネラの形態をそのまま固定するの が難しい，そこで試料調製には，細胞を瞬時に凍らせること ができる凍結固定法を取り入れた．凍結固定法には，大きく 分けて急速凍結法と高圧凍結法 (加圧凍結法; high-pressure freezing) がある. 急速凍結法では, 水晶無く凍結できる厚さ が約 $20 \mu \mathrm{m}$ と凍結範囲が狭いため, 20-100 $\mu \mathrm{m}$ と大きな細胞 を含む植物組織には不向きである. 我々は2 $200 \mu \mathrm{m}$ 以上の 厚みを凍結固定できる高圧凍結法により試料調製を行った。 高圧凍結法とは, 試料に約 2000 bar の高圧を加えると同時に 液体窒素により物理固定する方法で, この高圧により水晶の 発生や成長を抑え, 試料の微細構造の損傷を防ぐことがで きる. 特に細胞内輸送に関わるオルガネラに注目して広域 TEM像を取得する場合は, この高圧凍結法を用いて試料調 製している.

具体的には, 植物器官 (根端, 葉, 茥頂など)を, 鋭利な力 ミソリで挫滅のないよう細切し, 直径 1.2-1.5 mm, 深さ0.2-0.4 $\mathrm{mm}$ の穴のあいた平板試料キャリアに載せる(図4A-D). キャ リア内を満たす溶液として, $0.1 \mathrm{M}$ ショ糖を含む MS 液体培 地または水を用いている. 細切後すぐに高圧凍結装置 (Leica EM-PACT: 図4E) で凍結し, 続いて凍結置換を行う。初めに, $-80^{\circ} \mathrm{C}$ で2〜 7 日間, $2 \%$ オスミウム・アセトン溶液による凍 結置換を行い, それから 2 日間かけて $4{ }^{\circ} \mathrm{C}$ まで温度を上げる。 凍結置換の際, 我々は超低温アルミブロック恒温槽として販 売されている温度制御プログラム機能付クライオポーター (サイ二クス社) で $-80^{\circ} \mathrm{C}$ から $4^{\circ} \mathrm{C}$ までの凍結置換を行ってい る (図4F)。本装置は装置自体が比較的安価で, 液体窒素を 使わないため簡便に出来る点で優れている. 試料をアセトン で洗い, Epon812 樹脂に置換・包埋後, ウルトラミクロトー 么 (Leica EM-UC7) で目的の組織全体が入る大きさで超薄切 片を作製する. 切片はホルムバール支持膜を張った単孔グ
リッド (孔径 $1 \mathrm{~mm} \times 2 \mathrm{~mm}$ ) に載せ, 酢酸ウラニルとクエン酸 鉛で二重染色した (図 4G). この方法により次項に示す例の 他, シロイヌナズナ茎頂や葉, タバコ根端, シロイヌナズナ 培養細胞など様々な植物種, 器官, 組織もしくは培養細胞で 良好な凍結固定像走得ている. しかしながら, 巨大な液胞を 含む $100 \mu \mathrm{m}$ 在超える大きな細胞を多数含む組織を凍結固定 するのは非常に困難であり, 今後の課題である.

\section{広域 TEM像自動取得システムを用いた組織および培養細 胞の観察}

本システムを用いて, 様々な組織や細胞を自動撮影し, 広域TEM像取得に成功している. 本稿では, 具体例とし て高圧凍結固定したシロイヌナズナ根端とタバコ培養細胞 BY-2株について述べる.

\section{（1）シロイヌナズナ根端の広域 TEM撮影}

高圧凍結/凍結置換法により調製した発芽 7〜 14日目のシ ロイヌナズナ根端をEpon812樹脂に包埋し，そのブロックか ら広域超薄切片を作製した (図4AとB). 連続切片を単孔グ リッドのホルムバール支持膜上に, しわが入らないよう掬い 上げ, 乾燥させ二重染色した (図 $4 \mathrm{H}$ ). そのグリッドを電顕 用試料ホルダーに載せ, 広域TEM 自動撮影システムにより, リボソームや小胞が識別できる倍率 (JEM-1400・ボトムマウ ントCCD カメラで 12,000 倍) で約 3,000枚の TEM像を得た. さらに得られた写真を TEM像タイリングプログラムのビーム タイリングプログラムにより結合させ, Photoshopの手動ソー 卜と自動合成ツールを組み合わせることで1枚の画像を得た (図 5A). 光学顕微鏡レベルで観察可能な液胞や核以外の オルガネラでも各組織によって分布や形態が異なることがわ かった. また, トランスゴルジ網や分泌に関わる小胞クラス
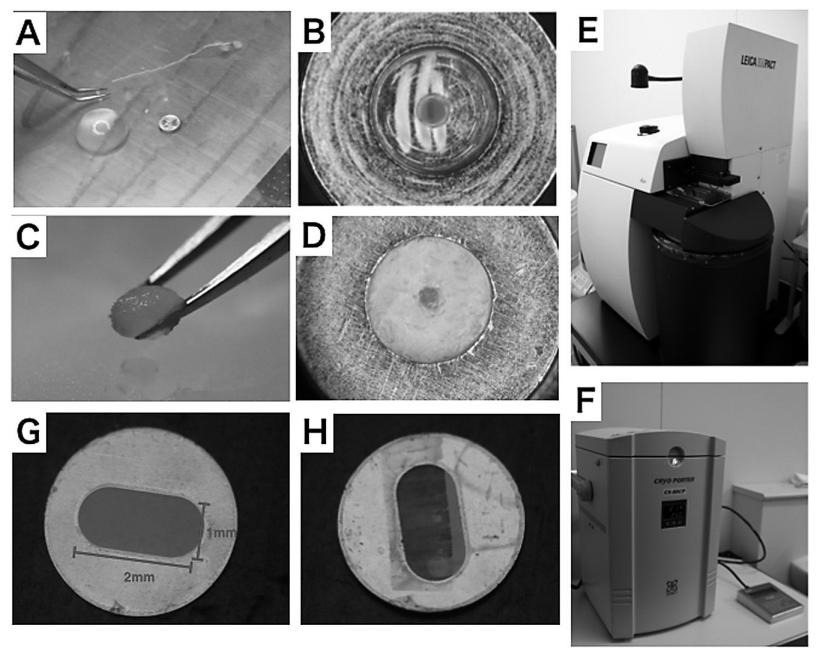

図4 広域高圧凍結切片作製の概要.（A）シロイヌナズナの根端を MS 培地内で細切し, 平板試料キャリアに搭載.（B）シロイヌナズナ の根端約 $1 \mathrm{~mm}$ 老 3 本載せた平板試料キャリア. (C) 水分在軽〈吸い 取りピンセットですくい上げた BY-2 細胞. (D) 空気が入らぬように BY-2 满たした平板試料キャリア. (E) 高圧凍結装置. (F) 凍結置換 に用いている温度制御プログラム機能付超低温アルミブロック恒温槽. (G) ホルムバール支持膜を張った単孔グリッド (孔径 $1 \mathrm{~mm} \times 2 \mathrm{~mm}$ ). （H）シロイヌナズナ根端全体を含む連続超薄切片を載せた単孔グリッ ド.
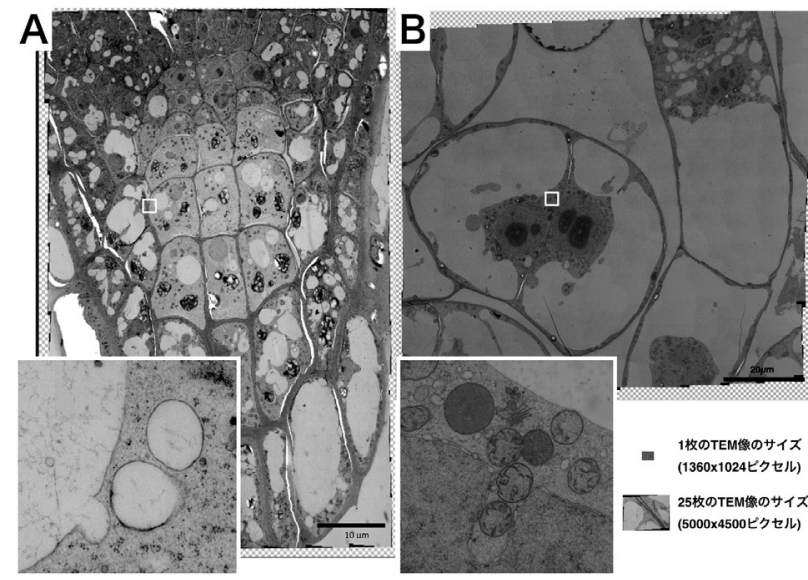

図 5 シロイヌナズナ根端とタバコ培養細胞BY-2 の広域TEM像 高圧凍結技法により調製したシロイヌナズナ根端とBY-2 細胞の超薄 切片を広域TEM像撮影. ビーム制御により撮影した 25 枚の TEM像 在ビームタイリングプログラムにより結合し, そのビームタイリング像 をPhotoshopの手動ソートと結合プログラムにより1枚のタイリング像 走得た。 (A) 発芽2週目のシロイヌナズナ根端領域の広域 TEM 像. 3,025 枚の写真を撮影・結合し, ファイルサイズ $2.19 \mathrm{~GB}, 29,000$ ピク セル $\times 45,000$ ピクセルの写真在得た. 左下は口の部分の拡大写真. (B) 対数増殖期の BY-2 細胞の広域 TEM像. 3,825枚の写真を撮影・ 結合し, ファイルサイズ $1.28 \mathrm{~GB}, 39,721$ ピクセル×37,020ピクセル の写真在得た. 左下は口の部分の拡大写真. 右下は, デジタル写真 1 枚のサイズと, ビームタイリングで 25 枚つなぎ合わせた写真のサイ ズを示す。 
ターは大きな表皮細胞なぼに多く, さらに, ERボデイ様の構 造体は側部根冠領域に多く観られ, 組織間でオルガネラの 分布や形態が大きく異なることが見えてきた。

\section{（2）タバコ培養細胞 BY-2 株増殖期の広域 TEM撮影}

対数増殖期 (継代 3 日目) の培養細胞を平板試料キャリア に載せ, 高圧凍結した後, オスミウム・アセトン溶液で凍 結置換した.アセトン洗浄後, 糖タンパク質と膜のコントラ ストを上げるために, 我々は $1 \%$ タン二ン酸・アセトン溶液 によるブロック染色在行っている(Toyooka et al. 2009). タ ンニン酸は特に糖タンパク質を良く染め, 酵母ではポストゴ ルジ区画が良く染まることが報告されている (McDonald and Muller-Reichert 2002)。この方法はRandy Schekman研究室 の Susan Hamamoto 氏からの情報を元に, 高圧凍結/凍結置 換法に応用した. Epon812 樹脂包埋後, 以降 (1) と同様に通 常より大きめの超薄切片を作製し，TEMにセットした．凍結 が良好でかつ目的の細胞周期・方向性を持つ細胞を選び, 倍率 12,000 倍で広域TEM 撮影システムにより撮影し, 3,000 から 5,000枚の写真走得た. ビームタイリングプログラムと Photoshopの手動ソートと結合プログラムを併用し, 広域高 解像度 TEM 像を得た (図 5B). 細胞全体の微細構造が容易 に見えるとともに，高圧凍結技法で固定したことにより，ライ ブイメージングでないと見えないような輸送途中の小胞や膜 構造など多数確認することができた (図 $5 \mathrm{~B}$ 拡大写真). 対数 増殖期と定常状態期の広域TEM像から輸送系オルガネラを 定量した結果, 対数増殖期から定常状態期にかけてゴルジ 装置の層板数と大きさ・小胞クラスターの数とその小胞数 は減少していたことから, 分泌系オルガネラは急速に減衰す ることが見えてきた，このような現象は，限られた部位の高 倍率撮影・観察では得られない知見である.

\section{広域TEM像自動取得システムの応用と今後の展望}

広域TEM像自動取得システムにより通常では撮影できな いギガピクセルクラスの TEM像を得られるようなつた. しか し, 取得した広域 TEM像のファイルサイズは, 数 GB～数 十GB と非常に大きいため, Photoshop など特殊アプリケー ションでなければ観ることができない，そこで我々は，理研 CSRS の持田・櫻井らとともに, 広域 TEM像をウェブブラウ ザ上で容易に閲覧/検索することができる「電顕アトラス」の 構築を進めている. 今後, タブレット型デバイスやスマート フォンがさらに普及し, 高校や大学などの教育現場で導入さ れていくと予想される. 誰でも簡単にアクセスできるインター フェイスで, OSやブラウザーに依存しない顕微鏡像のデー タベースを作成し，そこでオルガネラに印を付けた細胞小 器官から組織レベルまでの広域TEM像を電子地図のように シームレスに標示できれば, オミックス情報や他のデータ ベースと統合できるようになるとともに，TEMを扱つたこと のない研究者や学生でも容易にTEM像の閲覧が可能となる と期待される.

さらに, 撮影した広域TEM写真を用いて, 東大の桧垣らと ともに, 特定の注目した微細構造を半自動的に検出するプロ グラムを開発している. これは, 蛍光顕微鏡画像や核磁気共 鳴画像なぞ, 多様なバイオ画像を目的別に評価・分類する ことのできるCARTA: Clustering-Aided Rapid Training Agent (Kutsuna et al. 2012) を広域TEM像に応用している. 現在, ミ
トコンドリアやプラスチドなど特定のオルガネラ検出が可能 となりつつある。

近年, 集束イオンビームやウルトラミクロトーム機能をも つ高分解能走查電顕により広域かつ 3 次元の電顕像が得ら れるようになりつつある (Lichtman and Denk 2011). しかし ながら, そのような機器は非常に高価でランニングコストが かかり, 技術的にはいかにコントラストを上げるか, 大容量 の3Dデータをどのように扱うか, など問題点も多い. 我々の 広域 TEM像自動取得システムは, CCD カメと電動 X-Y 久 テージを搭載したTEMであれば(現状では日本電子製のみ 対応), MATLABとJEM ToolBox をインストールした外部PC 支導入し, 我々が開発したスクリプトを実行するだけで広域 TEM 画像を取得でき, TEM像タイリングプログラムで画像 をつなげ合わせることができる。

開発時に問題になったのは, 広域 TEM像のファイルサイ ズである. 広域TEM像は汎用ファイル形式の TIFFで, ファ イル全体で数 $\mathrm{GB}$ 数十 GBに達し, また, ピクセルサイズも 10 億 (ギガ) ピクセルを優に超える.このような大きなファイ ルは，条件を満たしたパソコン・OS・アプリケーションで なくては报うことができず，扱えたとしても動作不安定になる ことが多い.そのため, 大容量メモリと大容量なハードディ スクを要し, 我々はタイリングの際, 96 GBまたは 128 GBの メモリを搭載し，10テラバイト（TB）のハードディスクを搭載 するデスクトップPCを用いている.さらに，ファイルフォー マット形式には最大ファイルサイズまたは最大ピクセル数の 上限があり, また, LANやサーバーなぞネットワーク経由で 転送する際のファイルサイズの上限があるため, 今後はファ イルを分割してタイリングするなど工夫が必要である.

広域TEM像自動取得システムにより, 今まで得られなかつ た広域TEM像を簡便かつ短時間で取得できるようになつた。 撮影した広域TEM写真は, オルガネラの分布や超微形態 観察だけでなく, シミュレーションの基礎データや画像統合 データベース, 教育など様々な用途が考えられる. 全自動撮 影と結合システム改良し広域TEM像取得法の確立をより 確実なものにするとともに, 光学顕微鏡や高分解能走査電顕 との融合, データベースや3 次元解析などの応用を目指して いきたい.

\section{謝辞}

本稿では日本植物学会第 76 回大会で行なわれたシンポ ジウム「新世代の画像情報が切り拓く世界」の内容支中心に 扱つた。 オーガナイザーの鮫島正純 先生 (NPO 綜合画像研 究支援) ならびに大隅正子 先生 (NPO 綜合画像研究支援) にはこの場を借りて感謝申し上げます。本システムの開発に あたり, 東京大学新領域の桧垣匠 博士, 秋田佳恵 氏, 馳澤 盛一郎 先生, 日本女子大学の澤木史江 氏, 小林恵 氏, 理 研 CSRS の若崎眞由美 氏, 橋本恵 博士に多大なるご協力を 頂きました．また，九州大学の松岡健 先生にはタバコ培養 細胞の広域 TEM解析に助言を頂きました. システムインフ ロンティア社の古河弘光 氏, 片桐康代 氏にはJEM Toolbox を用いた広域TEM撮影プログラムのセットアップと助言を頂 きました. 理研 CSRS の持田恵一博士, 吉田拓広 氏, 櫻井 哲也 氏には電顕アトラスの構築に多大なるご協力を頂きま した。この場䞟借りてお礼申し上げます。本研究は, 科学研 究助成金 若手研究 (A) 24687007 (代表 : 豊岡), 挑戦的萌 
芽研究 23657051 (代表 : 豊岡), 新学術領域研究 23120526

(代表：永田), 若手研究 (B) 24770038 (代表：朽名)によ る支援受けました。

\section{引用文献}

Arimura, S., Yamamoto, J., Aida, G. P., Nakazono, M., and Tsutsumi, N. (2004) Frequent fusion and fission of plant mitochondria with unequal nucleoid distribution. Proc Natl Acad Sci USA 101: 78057808.

Bock, D. D., Lee, W. C. A., Kerlin, A. M., Andermann, M. L., Hood, G., Wetzel, A. W., Yurgenson, S., Soucy, E. R., Kim, H. S., and Reid, R. C. (2011) Network anatomy and in vivo physiology of visual cortical neurons. Nature 471: 177-182.

Kitajima, A., Asatsuma, S., Okada, H., Hamada, Y., Kaneko, K., Nanjo, Y., Kawagoe, Y., Toyooka, K., Matsuoka, K., Takeuchi, M., Nakano, A., and Mitsui, T. (2009) The Rice alpha-Amylase Glycoprotein Is Targeted from the Golgi Apparatus through the Secretory Pathway to the Plastids. Plant Cell 21: 2844-2858.

Kutsuna, N., Higaki, T., Matsunaga, S., Otsuki, T., Yamaguchi, M., Fujii, H., and Hasezawa, S. (2012) Active learning framework with iterative clustering for bioimage classification. Nat Commun 3: 1032.

Lichtman, J. W., and Denk, W. (2011) The Big and the Small: Challenges of Imaging the Brain's Circuits. Science 334: 618-623.

McDonald, K., and Muller-Reichert, T. (2002) Cryomethods for thin section electron microscopy. Methods Enzymol 351: 96-123.

Schermelleh, L., Heintzmann, R., and Leonhardt, H. (2010) A guide to super-resolution fluorescence microscopy. J Cell Biol 190: 165-175.

Toyooka, K., Goto, Y., Asatsuma, S., Koizumi, M., Mitsui, T., and Matsuoka, K. (2009) A Mobile Secretory Vesicle Cluster Involved in Mass Transport from the Golgi to the Plant Cell Exterior. Plant Cell 21: 1212-1229.

Yamada, K., Nagano, A. J., Nishina, M., Hara-Nishimura, I., and Nishimura, M. (2008) NAI2 Is an Endoplasmic Reticulum Body Component That Enables ER Body Formation in Arabidopsis thaliana. Plant Cell 20: 2529-2540.

Received: 31 January 2014 